\title{
Bone Marrow Purging
}

National Cancer Institute

\section{Source}

National Cancer Institute. Bone Marrow Purging. NCI Thesaurus. Code C51992.

Removal of cancerous cells from bone marrow before it is transplanted. 